ENTREPRENEURSHIP AND SUSTAINABILITY ISSUES

ISSN 2345-0282 (online) http://jssidoi.org/jesi/

2019 Volume 7 Number 2 (December)

http://doi.org/10.9770/jesi.2019.7.2(28)
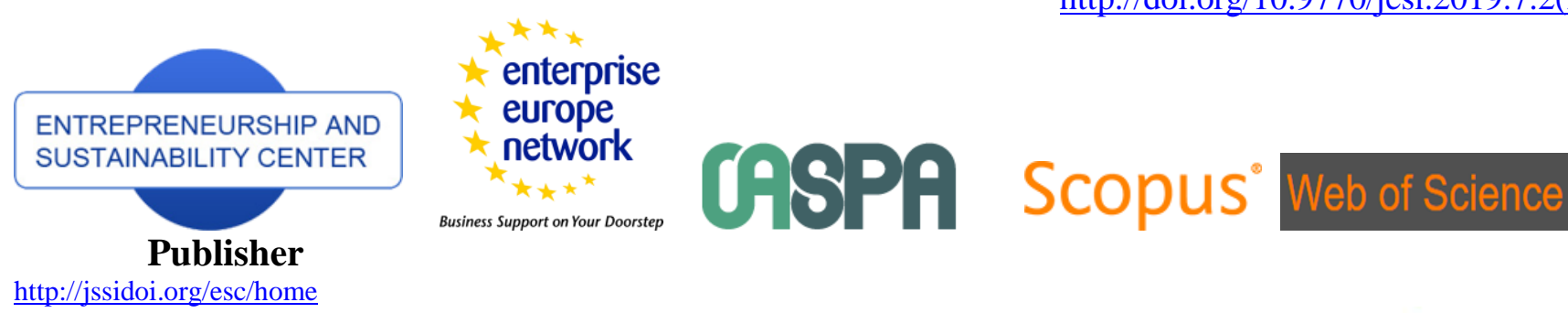

http://jssidoi.org/esc/home

\title{
TARGETS DETERMINATION MODEL FOR VAT RISKS MITIGATION AT B2B MARKETPLACES
}

\author{
Ravil Akhmadeev ${ }^{1}$, Tatiana Morozova ${ }^{2}$, Olga Voronkova ${ }^{3}$, Alexey Sitnov ${ }^{4}$ \\ 1,2 Plekhanov Russian University of Economics (PRUE), Stremyanny Lane 36, 117997, Moscow, Russian Federation \\ ${ }^{3}$ Altai state University, Lenina Str. 61, Barnaul, Russian Federation \\ ${ }^{4}$ Financial University of the Russian Federation Government, Leningradskiy prospekt, 49, 125993, Moscow, Russian \\ Federation \\ E-mails:ㅁam_rav@mail.ru; ${ }^{2}$ isfyrmorozova@gmail.com ; ${ }^{3}$ olka2004@yandex.ru; ${ }^{4}$ ASitnov@fa.ru
}

Received 12 March 2019; accepted 30 July 2019; published 30 December 2019

\begin{abstract}
The objective of the study is to assess practical requirements for VAT implementation in relation to B2B e-commerce participants for the development and practical implementation of target determination model, considering the mitigation of tax risks associated with transactions on digital marketplaces, taking into account data disclosure upon corporate reporting submission. It was determined in the course of scientific and practical study of the specifics of implementation and payment of indirect taxes, that there is no general methodological approach to indirect taxation of international services accomplishment in the field of B2B e-commerce, due to the differences in the indirect taxes applied: VAT or retail tax. In this regard, the hypothesis is proposed that the provision of optimal tax conditions for electronic marketplaces to a considerable degree is fraught with the shift in business opportunities towards B2B transactions in tax jurisdictions, providing equal conditions for non-residents. In terms of international practice, the study is of significant interest as the experience of introduction of VAT implementation and payment in relation to B2B operations, VAT-exempt transactions, given that the tax and regulatory system of the jurisdiction under study is assessed as a system with increased business risks. The above calculations showed that B2B non-resident is in unequal conditions compared to the taxpayers of a particular jurisdiction, and the difference in the calculated VAT value is significant. However, the introduced obligation to pay VAT has not provoked the non-residents to move to the e-commerce marketplace of other tax jurisdictions. The risk zones identified during the study determined the essential need to build an optimal model on digital marketplaces, which, in our opinion, can be the basis for the development of the targets for mitigation of the tax risks associated with VAT payment on B2B marketplaces. In our opinion, the proposed model is universal for all business management systems and applied ERP systems, taking into account the provision of all parties in B2B transactions with access to information. According to the results of the study, it was determined that the disclosure of information on B2B operations, indirect taxes and tax risks in corporate reporting is not imputed by the regulators and has a largely inconsistent and unstructured nature. In this regard, any proactive disclosure in corporate public reporting on B2B is possible only if the company treats the information requests from external users as significant, taking into account the calculation of the cost of preparation of the information, which does not exceed the expected effects.
\end{abstract}

Keywords: digital economy; electronic commerce; indirect taxes; VAT; tax base, tax rates; tax optimization; tax jurisdictions

Reference to this paper should be made as follows: R. Akhmadeev, T. Morozova, O. Voronkova, A. Sitnov. 2019. Targets determination model for VAT risks mitigation at B2B marketplaces, Entrepreneurship and Sustainability Issues 7(2): 1197-1216.

http://doi.org/10.9770/jesi.2019.7.2(28)

JEL Classifications: H21, F38, G38 


\section{ENTREPRENEURSHIP AND SUSTAINABILITY ISSUES}

ISSN 2345-0282 (online) http://jssidoi.org/jesi/

2019 Volume 7 Number 2 (December)

http://doi.org/10.9770/jesi.2019.7.2(28)

\section{Introduction}

The digital economy segment is a relevant area of research due to significant changes in the international business sphere. The emergence of new business communication technologies, electronic platforms allow the producers of goods (works, services), and the purchasers to reduce the transaction costs associated with the interaction. Companies from around the world use the electronic marketplaces to promote their products, getting the opportunity to expand the list of loyal customers, increase the sales and the amount of income without additional significant investment. Electronic trading platforms can be considered as a convenient and affordable service for all types of business, as the organizations get the opportunity both to sell goods to end customers on B2C or C2C models, and to conclude large and small wholesale transactions on B2B and B2B2C models. For commercial needs, a business management center may be located in one country, while the information and processing can be stored and performed in another country or other countries (Tarman, 2018; Plaskova et al., 2017). This is characteristic not only for multinational corporations with an extensive structure of the parent and controlled companies, but also for small one-component companies, which in certain jurisdictions will relate to small and medium-sized businesses. In this regard, there are several problems associated with the jurisdiction of the transaction in the event of a conflict of interest. One of the issues to be discussed is the procedure for indirect tax implementation (Leonteva et al., 2018). Historically, the EU, USA and emerging market countries have different taxation systems, primarily indirect taxation ones. At the same time, the international experience in B2B ecommerce taxation is characterized by different approaches to the procedure for their implementation and payment, since the Internet commerce is characterized by a cross-border feature of operations and the absence of physical borders, moreover, it is quite difficult for tax administrations to link the sales of services to the territorial jurisdiction of a particular country (Korableva et al., 2018; Singareddy et al., 2019). Also, any geographical location may be the place of origin of the electronic services provided (Peacock A. 2012). To a large extent, the groups of countries belonging to the EU, as well as the United States and the countries with developing markets have different approaches to the procedure for determination of the object of taxation and withholding of indirect taxes. Moreover, the common denominator is the revenue side of the state budget, determined by the jurisdictions using their approach, giving the main role to the tax administration of the regulatory authorities.

Practically, most countries implement indirect taxes on all goods supplied to their jurisdiction. In addition to indirect taxes payment, there is an obligation to pay customs duties (in respect of goods), taking into account the threshold values established by each country. To a large extent, this method of the chosen fiscal policy is the modern trend in the e-commerce recommended by the OECD as the provision of optimal compliance with the regulation of world cross-border trade. At the same time, according to Asongu (2012), the introduction of various tax mechanisms makes it possible to level the tax burden between the residents and non-residents to a certain extent. However, maintaining a balance between the interests of the state and taxpayers, in our opinion, should not make the non-residents lose their interest in local sales markets, while ensuring fair competition for the residents of a particular country in the field of B2B e-commerce. Since the current mechanism for indirect taxation, as a rule, contains a general taxation function - fiscal one, it is important to observe the interests of the subjects of the e-commerce tax process - organizations that are participants in B2B, B2C.

Another issue that needs discussion is the access to information for all parties interested in the B2B transaction process. This refers to the world's leading participants, providing audit and consulting services, including in the field of taxation and legal services, as well as in the field of market research, monitoring and forecasting, including the disclosure of information elements in corporate reporting in various segments (Kosorukov and Maksimov, 2016). One of these segments, the information on which is of interest to the stakeholders, is the services provided by B2B (Besley, 2013). In particular, epizootic disclosures by some companies in financial or other types of reporting, as a rule, do not provide sufficient material to determine the vector of change in the 


\section{ENTREPRENEURSHIP AND SUSTAINABILITY ISSUES}

ISSN 2345-0282 (online) http://jssidoi.org/jesi/

2019 Volume 7 Number 2 (December)

http://doi.org/10.9770/jesi.2019.7.2(28)

indicators for the B2B segment. Moreover, in the studies and analytical surveys on market monitoring and forecasting, performed by the companies, it is noted that some companies try not to disclose the information on the size and dynamics of services in the B2B segment (Keen, 2010). As a rule, this is a consequence of nondisclosure in order to maintain a competitive advantage. However, the disclosure of the information on the B2B sector in the statements of the companies may be associated with the company's own tax risks. This predetermines the growing interest of numerous stakeholders in the order of influence of taxation on the business as a whole. If the legislation of a particular jurisdiction does not provide for the disclosure of the information on certain sectors, then the decision belongs to the sphere of professional judgment of the reporting compilers and company management. In our opinion, due to large-scale changes in the digital segment of the B2B economy, general approaches to the disclosure of the information should be defined. At the same time, the interests of both the users and reporting compilers should be taken into account.

On the basis thereof, the purpose of this study is to assess the practical aspects of VAT implementation and develop a targets determination model for mitigation of the tax risks associated with the transactions on digital marketplaces and their disclosure in corporate reporting.

\section{Literature review}

In most scientific studies concerned with the problems of electronic commerce taxation, B2B is characterized by the consideration of theoretical aspects, taking into account the obtained empirical data, the procedure for indirect taxes implementation and payment. The nature of progressive development is common to B2B trade, as the individual countries, China in particular, have not made a final decision at the legislative level on the method of taxation of the cross-border transactions.

The study of the degree of influence of the indirect tax - VAT - on trade volumes is focused on a distortion of competition and injustice of taxation for both residents and non-residents in the B2B segment. For example, in a study carried out by Bach (2000), if foreign providers sell the services to end consumers via the Internet, then VAT should be implemented in the country where such services are consumed. The largest contribution to the consideration of the theoretical aspects of the e-commerce taxation of B2B and B2C in the EU countries is summarized in the studies carried out by Silva (2014), in which the current European tax legislation regarding cross-border transactions for the companies operating within the EU member states is overviewed most thoroughly. At the same time, the current European system of VAT implementation on cross-border trade is to a greater extent a significant barrier to entry into the common market for small businesses (Keeny, 1999; Dunets et al., 2019; Peshkova et al., 2017). In our opinion, this circumstance is quite justified, since there are differentiated threshold restrictions for all categories of taxpayers. For example, the revenue per year varies from 5300 Euro in Norway, 50000 Euro in Latvia. When paying VAT in the country of destination, the difference in the current tax rates between the country of origin (for example, in Hungary the rate is equal to 27\%) and destination (for example, in Luxembourg the rate is equal to 17\%) is significant. According to Papagiannidis (2008), in this case, sales companies are more likely to be registered as a taxpayer to pay the tax in the country of destination where a lower VAT rate has been introduced.

Despite the harmonization in the EU countries in accordance with the Sixth Directive, tax legislation contains, according to Kaplan (2009), a complex procedure for determination of the object of VAT taxation, a heterogeneous approach to different categories of taxpayers, and, given Schlosser (2006) studies, the situation is aggravated by the differences in the internal regimes of EU member states (by their own regulations). At the same time, the scientific research by Rene (2009) are addressed these problems in the early stages of building of the allEuropean construction for indirect taxation and double taxation regarding gambling in the Netherlands, carried out via the Internet and managed by the companies located in other jurisdictions. 


\section{ENTREPRENEURSHIP AND SUSTAINABILITY ISSUES}

ISSN 2345-0282 (online) http://jssidoi.org/jesi/

2019 Volume 7 Number 2 (December)

http://doi.org/10.9770/jesi.2019.7.2(28)

At the same time, the current practice of taxation in the EU countries contains a general tendency: to obtain the right to a VAT tax deduction paid in the EU countries, in most cases non-resident companies engaged in electronic services, to a greater extent, receive an incentive to transfer to the EU jurisdiction with the opening of a permanent representative office. In our opinion, this factor is relevant, since it excludes the nature of double taxation on indirect taxes. However, the VAT refund mechanism for non-EU residents to a greater extent is not applied by its own national tax law. The point at issue is the impossibility of application of the VAT tax deduction paid to the budget of a foreign jurisdiction when filing a tax return in one's home nation, i.e. B2B organization is not entitled to reduce the calculated VAT on internal sales of goods (services) by the amount of tax paid outside its jurisdiction. This approach is described in sufficient detail in the methodological studies of Yapara (2015), noting an important aspect of the taxation problem, when suppliers and consumers - B2B participants are in different jurisdictions, the principle of uncertainty and double taxation on VAT arises (Sazanov and Akhmetshin, 2016; Sharafutdinov et al., 2018). Therefore, this is an extremely negative aspect of the further development of ecommerce in the global world. In continuation of this study, in our opinion, the uncertainty in the procedure for application of the indirect tax deduction is significant if, for example, VAT is applied in one country and the sales tax is applied in another. The possibility of solution of this problem, according to Dhillon (2007), is in the plane of concluding individual agreements on the avoidance of double taxation on indirect taxes.

However, the fast pace of development of global B2B trade between countries prevents the tax laws of national jurisdictions from timely practical legalization. In particular, the negotiations on an international scale regarding the submission of tax reporting on FATCA foreign accounts, introduced by law in the United States in 2010, were adopted by the European countries only in 2014, and by some countries of the Asian sector, in particular Vietnam, in 2016 (Borowiecki, 2018). Agreement processes on country-by-country reports or CbCR also have not been completed for many countries. Unlike the FATCA mechanism, which obliges financial companies to unilaterally submit the information directly to the US tax service, the exchange of financial information within the framework of CRS is mutual and is carried out between the tax services of the participating countries (Brazys, 2017). Consequently, the local tax authorities first accumulate the information at home, and subsequently carry out an equivalent exchange between the countries (Maguth and Koskey, 2019; Trofimova et al., 2019; Goloshchapova et al., 2018; Voronkova et al., 2019; Sasongko et al., 2019).

Another global problem related to B2B indirect taxation, according to Cui (2010), is the tax rates change frequency at the state level. In particular, in the United States, another indirect tax is applied - the retail sales tax, which in 2018 changed 619 times both for specific types and goods (Prosser, 2016; Goryushkina et al., 2018) and at the level of the states themselves, cities and local jurisdictions. Consequently, the procedure for determining the correct sales tax rate for the final B2B product in various tax jurisdictions is complicated (Dincecco, 2016), since the manager needs to determine the rules of which jurisdiction-country to apply to each online transaction, depending on the location of the buyer and seller. In this regard, with a greater degree of probability, it can be argued that tax functions in the global world often conflict with the current taxation procedure in a particular country (domestic tax law) and the transfer of taxation of cross-border electronic commerce in jurisdictions to the location of the final buyer.

At the same time, according to Bastiaens (2016), the expansion of the degree of influence of e-commerce in the global B2B space from China, at the legislative level, a legal mechanism for charging VAT for subjects of this sector of the economy has not been formed. Despite the current procedure for VAT implementation and payment at the basic rate of 17\%, tax losses in the field of electronic commerce in empirical studies by Wei (2018) only for 2017 amounted to $30 \%$ of the total tax revenue to the country's budget. In this regard, the method of taxation of the electronic commerce proposed by him - the delegation of the tax agent functions to a cybermediary (to a third party) will make possible more substantial expansion of the information on electronic transactions on the Internet, as well as the reduction of the number of tax audits conducted, improving the quality of tax administration 


\section{ENTREPRENEURSHIP AND SUSTAINABILITY ISSUES}

ISSN 2345-0282 (online) http://jssidoi.org/jesi/

2019 Volume 7 Number 2 (December)

http://doi.org/10.9770/jesi.2019.7.2(28)

(Lebedeva et al., 2016). At the same time, it is proposed to carry out the relations between third parties and tax authorities on a paid basis, which, in our opinion, will create an unnecessary additional corruption component between the subjects of tax relations. However, according to Wei (2018), the information received should be reflected in the framework of reporting under IFRS. But there are a number of obstacles. Firstly, not all jurisdictions recognize the IFRS standards and not all companies, including voluntarily, prepare reports on these standards. Many companies are limited to national standards close to the IFRS, for example, US GAAP. Secondly, in the practice of the company, other types of reports are compiled, which are mandatory or compiled voluntarily by the companies, according to best practices. Based on the zero point, the need for the separation of property, according to $\mathrm{He}$ (2009), for the purpose of doing business, predetermined the appearance of establishment in the form of a legal entity. In the modern interpretation, in the presence of certain features, such as the participation right, the right of the owners to control and manage the capital is implemented in the form of a corporation. A corporation, which can be an independent enterprise or a group, has a common goal, objectives, strategy, and corporate ethics (Timothy, 2017). Accordingly, all business information of the corporation will be provided through corporate reporting (Korableva et al., 2019). One of the types of corporate reporting, which is considered by many authors as a new evolutionary approach to the presentation of financial and non-financial information (Adams, 2011), is the integrated reporting. The authors' studies are focused on the formation of the structure of this type of report, the value of information for the users, including the analysis of the copyright works in the fields of integrated reporting (Rinaldi, 2018). The submission by the individual companies of extended reports on the digitalization of activities, the research on the information interests of the client base by large audit companies, the reports on the development of the B2B market by market research companies, indicate that the approaches to disclosure of the information on $\mathrm{B} 2 \mathrm{~B}$ companies in corporate reporting are quite relevant.

\section{Theoretical background}

In general, the following basic online trade models were developed based on international B2B taxation practice.

- Classic model - according to which a legal entity must be registered as a taxpayer in the respective country. Both domestic and imported goods are sold. When importing, full customs clearance is performed and internal customs rules and tax legislation are applied. As a rule, when the classical approach is used by the electronic marketplaces, online shops are required to pay customs duties and VAT when importing, as well as ensure technical compliance (certification), service (service centers), legal support (consumer protection). Moreover, compliance with the law directly affects the increase in the price of imported goods sold.

- Cross-border model - does not require the registration of a legal entity in the territory of a particular country as a taxpayer. In this case, the import of goods is carried out through international postal services directly to the end customers (individuals). To a greater extent, foreign online marketplaces are used in the form of intermediaries in the sale of goods in the territory of a particular country (Shatunova et al., 2019). At the same time, foreign online marketplaces transfer the tax and customs burden to the final recipient. In particular, when shipped by international postal services, the duty-free import limit for goods for individuals for personal use between the EAEU member countries since 2019 has been equivalent to the national currency to 500 Euros (in 2020 it will be reduced to 200 Euros) or $31 \mathrm{~kg}$ of weight per 1 person per calendar month (Ponomareva, 2019).

It should be noted that in fact the majority of goods imported in a cross-border way is provided by a facilitated duty-free import regime, which affects directly the competitiveness of local and foreign online stores. Thus, crossborder transactions in EU countries are carried out in compliance with a general procedure, regulated by the Customs Code of the European Union, establishing the exemption from VAT on parcels worth not more than 22 Euros (each state varies in value), and gifts worth not more than 45 Euros. Individuals are exempted from customs 


\section{ENTREPRENEURSHIP AND SUSTAINABILITY ISSUES}

ISSN 2345-0282 (online) http://jssidoi.org/jesi/

2019 Volume 7 Number 2 (December)

http://doi.org/10.9770/jesi.2019.7.2(28)

duties at parcels worth not more than 150 Euro per unit (Seelkopf, 2016). However, in our opinion, these rules discriminate the non-residents of the EU.

In the field of B2B e-commerce services, there is no general methodological approach to indirect taxation in the field of international B2B e-commerce services (Rixen, 2011). This is primarily due to the differences in applicable taxes: VAT or retail sales tax. Moreover, often e-commerce is cross-border and one of its key features is the lack of physical boundaries. In this case, the place of origin of the service provided is not tied to a particular jurisdiction. In this case, the lack of a common approach, in our opinion, is a serious problem for B2B participants located in different jurisdictions. Another problem of B2B e-commerce is the determination of the place of permanent representative office in case of commercial activities in the digital space. So, for the establishment of a permanent representative office in accordance with the generally accepted concept developed by the OECD, a permanent place of business is required. Such a place of business also requires a physical presence in the country. Traditionally, organizations had a physical presence in a country due to the existence of an office or point of sale, which made it easy to determine their presence using a specific geographic point (Wahl, 2010). However, the companies operating in the digital space do not have to open an office to conduct business in another jurisdiction. In this regard, the main problems of VAT administration in the field of electronic services are related to the taxation of cross-border transactions in the B2C segment, i.e. the procedure for delivery of the services from the company to the buyer (Thalassinos et al., 2012; Romasheva et al., 2018). These issues are mainly related to the determination of the jurisdiction in which the tax should be paid, taking into account the identification of the tax base. In this regard, consider the main features of the regulation of indirect taxation.

\section{Features of VAT regulation in the field of e-commerce in the EU}

Generally, in the case of B2B services, the VAT object of taxation is determined based on the location of the recipient of such services (the customer). Subject to the provisions of the Sixth Directive, the place of service rendering to a taxable person shall be the location (residence) of the recipient of such services (the customer). If service rendering is carried out by a permanent representative office of a taxable person located in a place other than his location, the territory of the permanent representative office shall be recognized as the actual place of service rendering.

In general, the B2C services provided are subject to VAT at the location of the provider. In this case, the place of service rendering to non-taxable persons shall be recognized as the location of the provider (Bittman et al., 2017). In the case of service rendering through the permanent representative office of the provider, the object of taxation will be recognized at the location of the permanent representative office. At the same time, when rendering B2B, B2C services, there are several exceptions concerning the procedure for determination of the VAT object for certain types of operations, for example, real estate, passenger transport, restaurant and catering services, auxiliary services, etc. Thus, to determine the VAT object, providers must have information about the status of the customer (is the customer a taxable or non-taxable person) and its physical location (Rupeika-Apoga et al., 2018). A distinguishing feature should be defined in the procedure for VAT calculation and payment in the EU countries when providing B2B services by using the concept of Reverse Charging VAT, which is as follows. The customer of the service, when filing a VAT tax return in his country, accrues the VAT payable to the budget at the local rate and simultaneously presents the amount of tax deductible. This can be applied by the recipient of the B2B service if the recipient is registered as a VAT payer (has the VAT number) in the relevant EU country. In this case, the recipient of the service must first inform the B2B provider of an individual identification number for verification on a common basis and for compliance with valid information about the counterparty.

In practice, this solution has been successfully applied by the established agency companies based on digital solutions that automatically retrieve sales data of a seller or any accounting software to generate electronic VAT returns in the MOSS system (Hyman, 2015). It should be noted that in cross-border transactions, the MOSS 


\section{ENTREPRENEURSHIP AND SUSTAINABILITY ISSUES}

ISSN 2345-0282 (online) http://jssidoi.org/jesi/

2019 Volume 7 Number 2 (December)

http://doi.org/10.9770/jesi.2019.7.2(28)

mechanism allows the taxpayers engaged in cross-border transactions within the EU not to register in each jurisdiction, but to submit VAT returns only in the country in which they have a permanent office.

For legal entities not located in the EU, the obligation to pay VAT in the territory of an EU member state also applies if the consumer of the goods sold is physically located in the EU. In this case, the non-resident of the EU is not entitled to apply a VAT tax deduction for the amount of tax paid in the EU country, which, in our opinion, leads to non-competitive pricing policy in the local market. Moreover, the current VAT audit rules are not harmonized in the European Union (Brülhart, 2014). This circumstance causes the risk of double taxation for nonresidents of $\mathrm{B} 2 \mathrm{~B}$.

\section{Features of tax and customs regulation in the field of electronic commerce in the USA}

The USA can be characterized in the field of electronic commerce by the application of tariff and non-tariff regulation measures, taking into account the interests of domestic manufacturers. Like any other country, they apply most favored nation treatment and preferential import in the form of special duties, while the rates vary up to $37 \%$ (Lindvall, 2011). In the case of sales, a sales tax is levied on the price, the rates of which depend on the type of goods and the territory of a particular state, the maximum rate is $11.5 \%$. When purchasing from ecommerce non-residents, the individuals are required to pay customs and tax duties, and the threshold for dutyfree import is not more than 800 US dollars (provided that the goods are not subject to quotas or prohibitions), the parcels worth up to 2000 US dollars should be accompanied by the inventory indicating the amount of the duty. Subject to the permission of the U.S. Supreme Court, since July 2018, sales tax on online trading may be withheld in the states, the rates of which vary from 2.9 to $8.3 \%$. At the same time, the current practice of self-declaration by an individual based on the results of the tax period did not allow to exercise proper control over the purchases by tax administrations. Consequently, withholding sales tax from sales by the company will make it possible to level the competition between conventional retail chains and online trading.

\section{Features of VAT regulation in the field of electronic commerce in Russia}

In Russia, a foreign B2B organization (an electronic services provider or an intermediary) mandatory computes and pays VAT for all transactions, regardless of the buyer of electronic services, that may be the individual, legal entity or the individual entrepreneur (B2C, B2B). In terms of the state, the main goal of VAT tax legislation amendment was to ensure the competition between Russian participants and foreign participants, who 2017 did not have to pay tax to the Russian budget until October (Lymar, 2018). In the current unfavorable macroeconomic conditions of the Russian economy, due to the equalization of the tax burden in B2B e-commerce sales when providing services in electronic form, the VAT rules were adjusted in favor of Russian B2B taxpayers (Karpova, 2018). Thus, the current procedure for the implementation and payment of the value-added tax is established when providing the individuals with the services in electronic form on the territory of the Russian Federation for:

a) foreign organizations, except for the provision of services through the established separate division in the territory of the Russian Federation;

b) intermediaries of foreign organizations (tax agents) engaged in entrepreneurial activities based on commission agreements (commissions, agency agreements, etc.).

At the same time, the changes in the taxation procedure affected the key foreign taxpayers subject to mandatory tax registration with the territorial bodies of the Federal Tax Service of Russia, in particular, "Google LLC.", "Apple Inc.", "Microsoft Corporation"; "eBay Inc." and "AliExpress", specializing in the organization of online stores as well as online marketplaces for the sale of computer games "Steam", etc. As an object of taxation for non-residents of $\mathrm{B} 2 \mathrm{~B}$, a closed list of types of services provided in the Russian Federation is used when selling the electronic content in the form of:

a) programs, games, applications and databases, including their updates, as well as the rights to electronic books, graphic images, music, etc. ("Digital goods"); 
b) when conducting online auctions, providing hosting services, storing databases, providing access to search engines on the Internet, registering domain names, administering information systems and sites on the network, etc.

Thus, tax regulation in the field of $\mathrm{B} 2 \mathrm{~B}$ e-commerce is aimed at balancing the tax burden between residents and non-residents.

\section{Data analysis}

The countries with developing market are characterized by the continuity of market mechanisms used in international practice to achieve a unity of approaches to the intercountry economic relations. The introduction of VAT in the territory of post-Soviet countries and Southeast Asia, for example, North Korea, India, is not the exception. The VAT was chosen instead of another indirect tax, for example, sales tax because VAT makes it possible to create a system compatible with European countries. For individual countries that view EU accession as the next stage of their economic reform, this is a prerequisite for joining the European Union. Moreover, the unity of approaches in the implementation of indirect taxes will contribute to the development of transnational business, as well as small and medium-sized enterprises, regardless of whether or not the country belongs to the EU.

The development of digitalization of the company, the provision of optimal tax conditions on electronic marketplaces can lead to a shift of business to transactions in a certain jurisdiction. In international practice, the experience of introducing VAT for transactions on B2B marketplaces where the transactions used to be VATexempt, may be interesting. In this case, there are reasonable assumptions that a number of companies may consider that the share of revenue attributable to this geographical sector of the economy is not significant and decide to trade on another e-market.

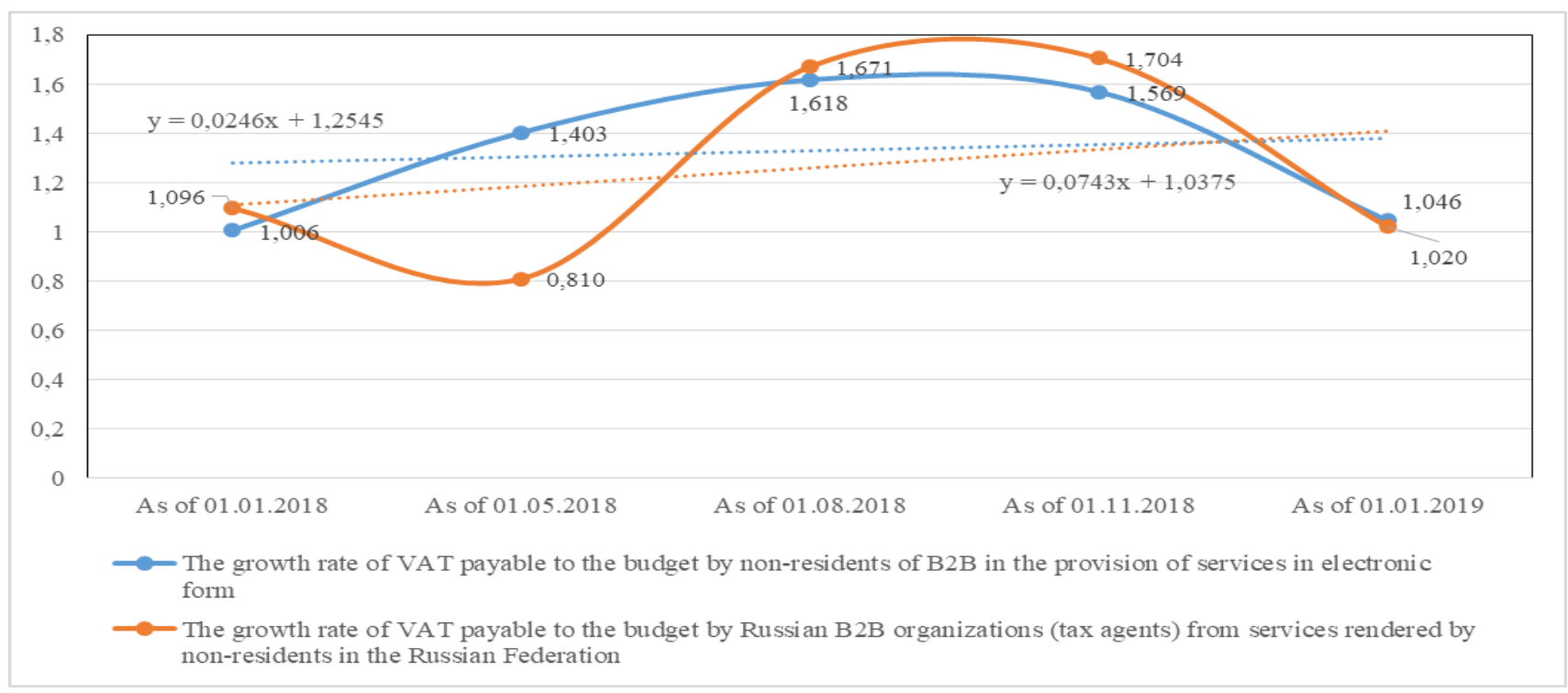

Fig. 1 Dynamics of the growth rate of the amounts of VAT payable to the budget of the Russian Federation by B2B payers. Compiled by the authors on the basis of the data provided by the tax service of the Russian Federation Source: https://analytic.nalog.ru/portal/index.en-GB.htm 
Consider the dynamics of the growth rate of the amounts of VAT payable to the budget by B2B non-residents and B2B tax agents (residents) from the moment of the introduction of tax legislation (submission of quarterly VAT returns) in relation to the provided electronic content services (Fig. 1).

The general dynamics of growth rates calculated using the general economic method of chain substitutions for the period 01.01.2018-01.01.2019 indicates a slowdown in the growth of tax revenues primarily from Russian B2B payers (Fig. 1). The calculation of the average growth rate of VAT tax revenues from taxpayer residents amounted to 0.9822 . This calculation is made according to the following average formula:

$\overline{T p}=\sqrt[n-1]{\frac{Y n}{Y 1}}$

where $\mathrm{n}$ - number of calendar quarters,

Yn - current indicator,

Y1 - base indicator for January 1, 2018.

In turn, the average growth rate of VAT tax revenues from B2B non-residents, calculated using formula (1), amounted to 1.0099 , which is characterized by a sustainable reaction and unchanged decisions in the development of the Russian market of electronic content services, even due to an increase of the basic VAT rate since January 01, 2019. It should be noted that despite the decrease from 1.5688 to 1.0461 in the growth rate of VAT tax revenues from B2B non-residents in the 4th quarter of 2018, the dynamics of the number of registered foreign B2B companies engaged in service rendering tripled in the period from 01.01.2018 to 01.01.2019 (Fig. 2). This circumstance testifies to a greater degree to the expansion of the activities of non-residents in the Russian market of Internet commerce.

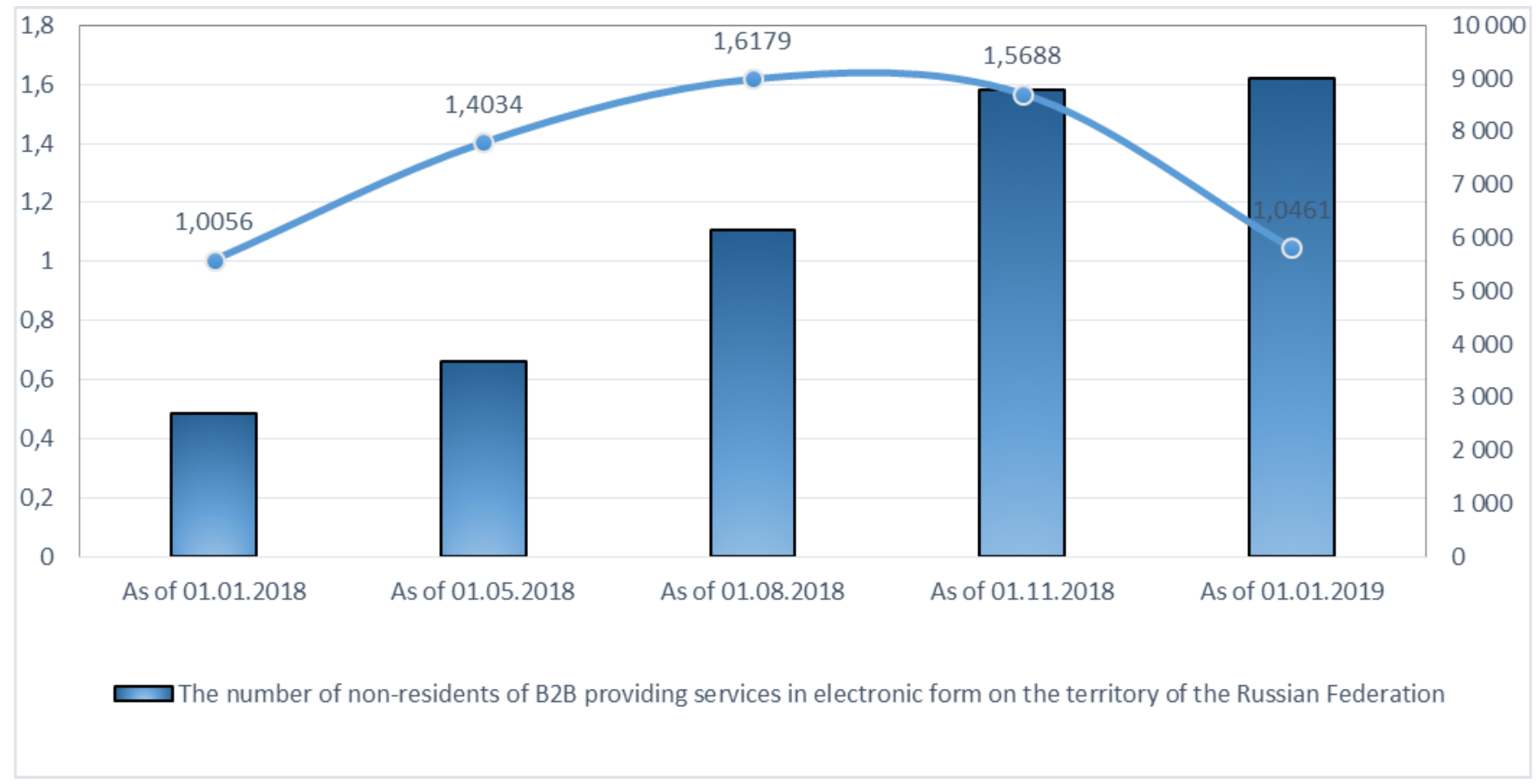

Fig. 2 The ratio of the growth rate of VAT payable to the budget of the Russian Federation and the number of existing foreign B2B companies

Source: https://analytic.nalog.ru/portal/index.en-GB.htm 


\section{ENTREPRENEURSHIP AND SUSTAINABILITY ISSUES}

ISSN 2345-0282 (online) http://jssidoi.org/jesi/

2019 Volume 7 Number 2 (December)

http://doi.org/10.9770/jesi.2019.7.2(28)

Under these circumstances, one important aspect that may affect the decision-making of B2B participants should be noted. Indirect VAT is a tax on final consumption and it is paid at each stage of production and distribution, therefore, each manufacturer or distributor pays it when selling goods (works, services). At the same time, in the world practice of VAT implementation and payment, this tax does not distort the production process and does not affect the company's choice of its legal form. The current principle of VAT neutrality implies that every entrepreneur is entitled to receive a tax deduction for the purchase of goods (works, services) regardless of the type and specificity of the object of taxation, as well as the source of financing and the legal form of relations. Thus, one and the same entity must receive an identical right to VAT deduction. At the same time, according to the Russian tax legislation, foreign B2B companies, selling electronic content in the Russian Federation, have no right to apply a VAT tax deduction. When calculating the tax base for a calendar quarter, such organizations pay tax at the estimated rate of $16.67 \%$ (15.25\% to 2019$)$.

In turn, Russian B2B companies are entitled to tax deduction, therefore, they reduce the tax base by the amount of the tax deduction by paying VAT at a basic rate of $20 \%$ (18\% to 2019).

The study showed that the introduction of the obligation to pay VAT, as well as the mandatory registration of non-residents with the Federal Tax Service did not provoke foreign companies to move to the e-commerce marketplaces in other jurisdictions, however, the sales volumes both from residents and non-residents decreased. In our opinion, this testifies to the intentions of the companies to expand their business capabilities and strengthen their competitiveness by participation in digital marketplaces of the countries with developing market economies, while the market itself is assessed as promising.

However, business shows enough caution in participating in B2B sales in emerging market jurisdictions. So, the largest B2B player "Mail.ru Group Limited", notes the following in its IASB reporting. Russian tax, currency and customs legislation is subject to varying interpretations, and changes, which can occur frequently. Management's interpretation of such legislation as applied to the transactions and activity of the Group may be challenged by the relevant regional and federal authorities. Recent events within the Russian Federation suggest that the tax authorities are taking a more assertive position in their interpretation of the legislation and assessments and as a result, it is possible that transactions and activities that have not been challenged in the past may be challenged. As such, significant additional taxes, penalties and interest may be assessed. Fiscal periods remain open to review by the authorities in respect of taxes for three calendar years preceding the year of review. Under certain circumstances, reviews may cover longer periods. The Group's management believes that its interpretation of the relevant legislation is appropriate and is in accordance with the current industry practice and that the Group's tax, currency and customs positions will be sustained. However, the interpretations of the relevant authorities could differ and the effect of additional taxes, fines and penalties on these consolidated financial statements, if the authorities were successful in enforcing their different interpretations, could be significant. At the same time, Mail.ru Group Limited does not disclose the information on the B2B sector either in IFRS or in other types of corporate reporting.

At the same time, another major participant, RUSNANO JSC, which conducts competitive procurement procedures in electronic form through the functionality of the B2B-Rusnano electronic marketplace, which is part of the B2B-Center unified electronic trading platform system, notes the following. The Group operates primarily in the Russian Federation. Accordingly, the Group's business is influenced by the economy and financial markets of the Russian Federation, which are characterized by the features of an emerging market. Legal, tax and regulatory systems are evolving, however, there is a risk of ambiguity in the interpretation of their requirements, which are also subject to frequent changes, which together with other legal and fiscal factors creates additional difficulties for the business of enterprises. At the same time, RUSNANO JSC does not disclose the information on B2B in its IFRS financial statements. However, in the annual report of the joint-stock company, it notes that the 


\section{ENTREPRENEURSHIP AND SUSTAINABILITY ISSUES}

ISSN 2345-0282 (online) http://jssidoi.org/jesi/

2019 Volume 7 Number 2 (December)

http://doi.org/10.9770/jesi.2019.7.2(28)

purchases carried out using B2B marketplace account for $94.8 \%$ of the total volume of all contracts concluded. However, according to the results of competitive procurement procedures, they account to $5.2 \%$ of the total volume of all concluded agreements.

It should be noted that the number of foreign Internet companies registered in the Russian Federation as VAT taxpayers in the provision of B2B electronic services as of August 1, 2019 was 1784 companies, 55\% of the total number of companies were sampled by the authors using the "random selection method" in relation to the data presented in the IFRS statements, US GAAP reporting. In general, the identity of professional judgment regarding the economic environment in emerging economies and the presence of significant tax risks associated with changing tax laws and the interpretation of tax laws by the regulatory authorities is common. It should be noted that the information contained in the audit report accompanying the IFRS reporting is a significant argument in the analysis of the situation. Thus, in the format of audit reports proposed by the Public Companies Accounting Supervisory Board (PCAOB) and approved by the US Securities Commission (SEC), the concept of "critical audit matters" i.e. the issues relevant to financial reporting, which can be complex and ambiguous, is used, the solution of which reaches the level of professional judgment. One of the critical audit issues identified in the audit reports is the issue of tax risks. Thus, the information on tax risks that reaches the level of professional judgment to a greater extent represents the risk of litigation in tax disputes, regular tax audits, many tax jurisdictions etc. At the same time, audit companies set a sufficiently low materiality threshold, which, as a rule, is $1 \%$ of the revenue. In particular, for a B2b participant, Vodafone Group it amounts to 215 million euros, while the reserve for expected legal tax risks amounts to 2000 million US dollars. Danfoss group of companies, with a significant revenue threshold of 392 million euros and the risk of tax litigations noted in the audit report, does not disclose the necessary information in absolute value in the financial statements. Consequently, the IFRS reports of the companies give only a truncated view of the performance of the company, which is mainly focused on compliance with regulatory requirements. At the same time, the procedure for information disclosure on tax risks associated with $\mathrm{B} 2 \mathrm{~B}$ is not covered. Basically, the companies are limited to standard wording on the ambiguity of tax systems in some jurisdictions and management's confidence in its correct interpretation. At the same time, the users of the reporting can estimate the magnitude of the threat only through information on the creation of reserves for tax risks and take into account critical audit issues in the audit report. At the same time, some information about the participation of the companies in B2B marketplaces and unsystematic data on some financial indicators can be found in other reports of the companies published on the Group's corporate portal or information disclosure server. In relation to the majority of B2B participating companies, the relevant information is not provided in either financial or other types of reports submitted in the public domain. In this regard, the problem of access to $\mathrm{B} 2 \mathrm{~B}$ information for the stakeholders, their information needs and the place of such information in corporate reporting, including a specific segment of the economy, remains unsolved.

\section{Results}

According to the results of the study and calculations, it can be confirmed that interest in digital marketplaces does not decrease among all B2B participants. However, the unfavorable economic situation, as well as a decrease in the purchasing power of the end users, may constrain the growth. In confirmation of the findings, the authors would like to cite expert assessments of the consulting company Frost \& Sullivan. It is forecasted that B2B ecommerce market will be doubled, 6.7 trillion USD by 2020 year, and $85 \%$ of transactions between suppliers and customers will be carried out without personal participation (Dorofeyev et al., 2018). At the same time, the B2B e-commerce industry is a global phenomenon, in 2018, compared with 2017 , in almost all countries there was a significant increase of no less than $7 \%$ based on the use of several business models: distributors (growth by 6.2 $\%$ ), manufacturers (7\%), retailers (26.6\%), wholesalers (5.4\%). Figure 3 shows the comparative data on B2B ecommerce sales to GDP as of 2017. 


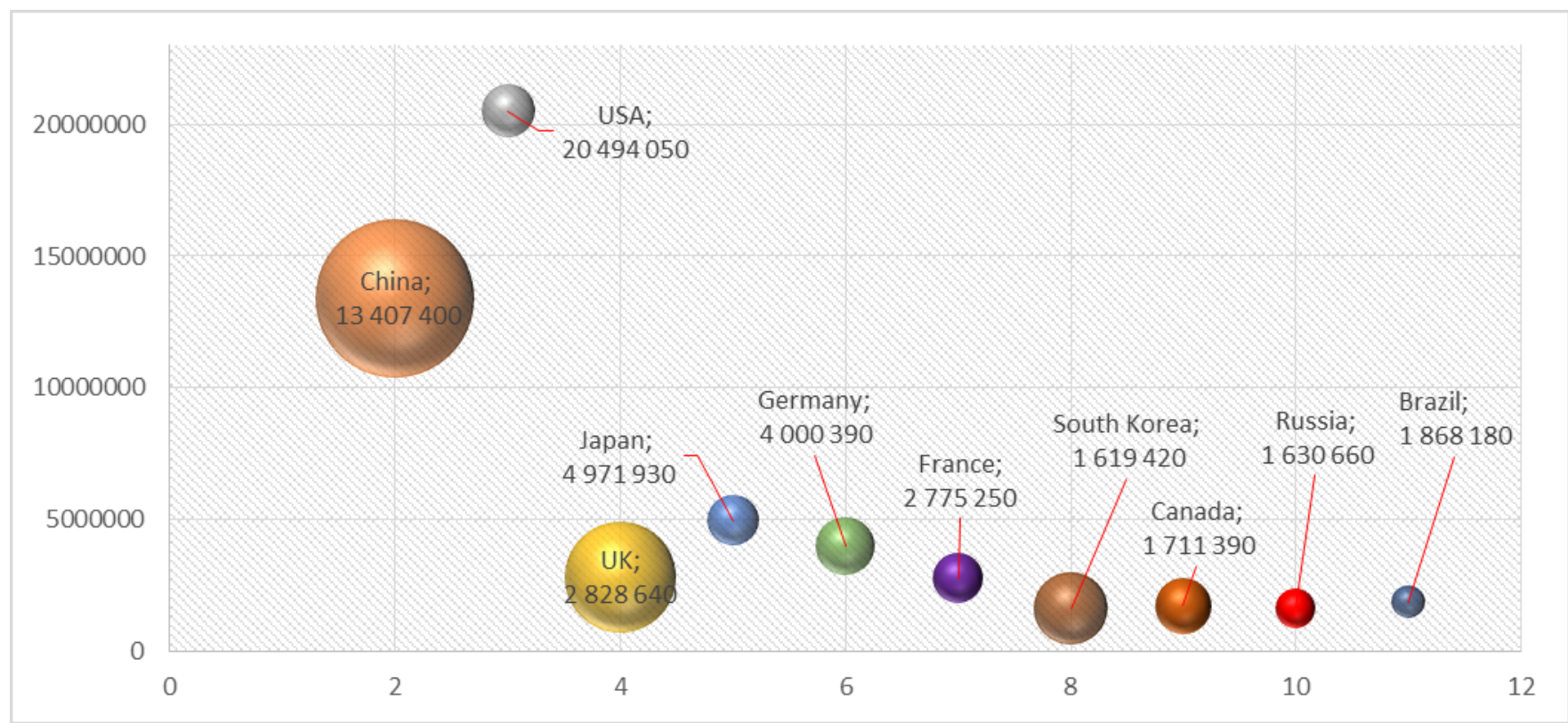

Fig. 3 Comparative characteristics of sales volumes for the most leading B2B e-commerce countries to GDP in 2017. Source: https://www.forbes.ru/biznes/pmef-2018361073

Due to a possible change in tax rules for non-residents of B2B in order not to distort competition and stimulate Russian B2B market participants, aimed at quality improvement of products (goods, services) provided to the consumers, the state should create more attractive conditions. One of the tax incentives aimed at the attraction of foreign participants to $\mathrm{B} 2 \mathrm{~B}$ electronic trading platforms is to establish a lowering coefficient to the current VAT rate for the non-residents offering goods and services. Let us calculate the VAT for the abstract type of electronic services offered for sale by a foreign non-resident and a resident B2B participant, assuming that their VAT tax base is equal. Naturally, within the framework of competition and marketing strategy, companies can both increase and lower it. However, we will proceed from this condition, since the proposed service is assumed to be identical in its consumer characteristics. In this case, B2B non-resident, selling a certain product or service, must pay VAT to the budget according to the following formula:

$V A T b 2 b=\sum T B \times(16,67 / 100)$

where $V A T b 2 b$ - VAT payable per calendar quarter;

$\sum T B-$ tax base for services rendered for a calendar quarter;

16.67 - current VAT rate for B2B non-residents.

In turn, a resident $-\mathrm{B} 2 \mathrm{~B}$ participant, selling a similar service, is obliged to pay tax to the budget according to the following formula:

$V A T b 2 b=\sum T B \times(20 / 120) \times(1-r)$

where $r$ - amount of own profit (or margin)

$20 / 120$ - current VAT rate, taken into account in the price of the service rendered.

Thus, B2B non-resident is in unequal conditions compared to a resident, and the difference in the calculated VAT value will be at least $(20 / 120) \times \sum T B \times r$. Since VAT refers to indirect taxes, it is paid by the end consumer. In fact, after the introduction of new VAT rules, for example, in Russia, Google LLC shifted the burden of tax payment to end customers, thereby increasing the price of the electronic product (Kevorkova, 2019). In turn, 


\section{ENTREPRENEURSHIP AND SUSTAINABILITY ISSUES}

ISSN 2345-0282 (online) http://jssidoi.org/jesi/

2019 Volume 7 Number 2 (December)

http://doi.org/10.9770/jesi.2019.7.2(28)

Apple Inc. shifted the VAT payment to the developers of iTunes Store software applications (Kolesnichenko, 2018). This affected the reduction in the profit of intermediaries, while the software prices remained unchanged for the end users. At the same time, the ambiguity of tax legislation in various jurisdictions, cross-border transactions on digital platforms cause an increased risk in the field of taxation, including indirect B2B taxes. This necessitates the development of a strategy for the tax function of all parties to a transaction to level out a conflict of interest. In addition to the internal strategy, it is also required to develop an external strategy to inform all transaction participants and potential interested parties. First of all, this is associated with the good will risks, which may be the result of incorrectly interpreted information about the company in the media and on the Internet. Consequently, the need for wider disclosure of the information in corporate reporting and participation in the implementation of global initiatives to ensure tax transparency in the B2B segment is increasing.

\section{Discussion}

The identification and development of measures to prevent tax risks are necessary to ensure the successful financial-economic activities of all companies. The justification and development of measures should be based on the specifics of the participation of companies on digital platforms and aimed at revealing the integrity of the object, identifying diverse relationships in it. The common risks are as follows:

- the risk of financial losses related to the interpretation of legislation by regulatory authorities and a taxpayer (Gugl, 2015);

- the risk of additional tax charges, imposing penalties, fines resulting from a dispute and refusal by the regulatory authorities of the reimbursement of value-added tax (full name);

- the risk of financial losses arising from office and field tax audits (Gennaioli, 2015);

- the risk of irrational actions of officials responsible for the control and management of tax obligations (Morkovina, 2018).

The authors consider it necessary to highlight the following specific risks for VAT associated with the participation on digital platforms. As a rule, when determining the object of VAT taxation, the place of sale would be the territory of the relevant jurisdiction when one of the following conditions is met:

a) the buyer's place of residence belongs to the jurisdiction in which the transaction was carried out;

b) the payment is made through a bank or an electronic money operator located in the jurisdiction in which the transaction was carried out;

c) the buyer's network address is registered in the jurisdiction in which the transaction was carried out;

d) the international country code of the phone number used to purchase or pay for services is assigned by the jurisdiction in which the transaction was carried out;

However, it is rather difficult to technically determine the actual place of sale of goods, especially for small online stores, in the system of which there are no necessary resources: order;

a) not all online stores require to enter passport data or an actual phone number at the time of placing the

b) the payment can be made by alternative online currency;

c) the buyer's network address does not give an unambiguous answer to its location, since it does not exclude the possibility of using a proxy server that allows the signal to pass through an alternative country.

In this case, the guideline for assessing real sales volumes in the $\mathrm{B} 2 \mathrm{~B}, \mathrm{~B} 2 \mathrm{C}$ e-commerce market for tax administrations in determining the tax base is only the submitted VAT tax returns. However, a fiscal surveillance mechanism in relation to non-residents, for example, during field tax audits, is not defined in tax legislation (Hyman, 2015). The current tax administration comes down to an analysis of the information submitted by B2B participants in tax returns, and they are not always correct.

In the context of these conditions, the authors do not set the task of developing a tax risk management system, since this is a separate study. But they think that the general algorithm of actions of the company's tax services should carry out at least the following actions: 
a) analyze of the types of the company's activities to determine the transactions that will or may be recognized as electronic services and, as a result, will lead to the need to register (if required by the laws of the jurisdiction) as a VAT payer;

b) analyze the possibilities of obtaining the exemption from VAT on certain transactions that are not subject to VAT or taxed at a zero rate or are exempt from payment in the relevant jurisdiction;

c) if necessary, revise the company's current business model, including the financial model, workflow to reduce tax risks for VAT on the digital marketplace;

d) consider the possibility of selecting and setting up an ERP system for the necessary accumulation and processing of information on transactions on electronic platforms, which may be useful for assessing tax risks, making managerial decisions and auditing.

Due to the increased participation of companies in the new digital environment, there is an urgent need to carry out all necessary actions to optimize taxation and prevent tax risks. In the authors' opinion, the local scheme for mitigating VAT tax risks on the digital marketplace can be presented in the following format (Fig. 4).
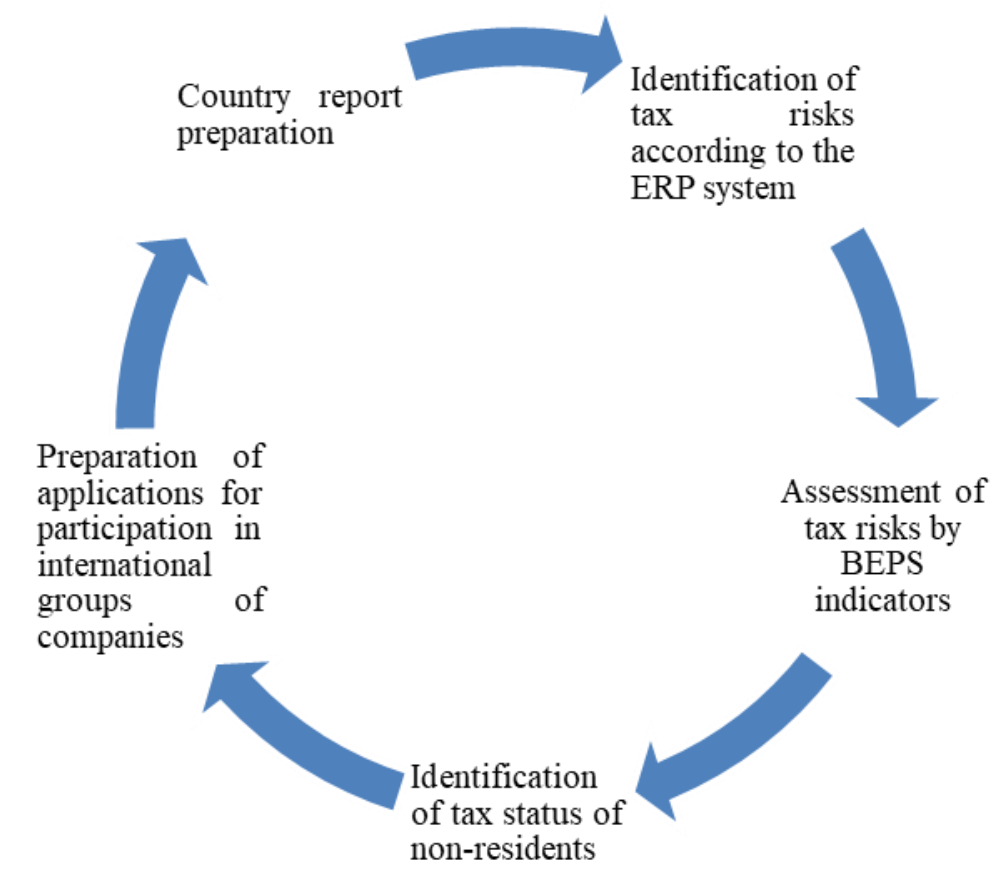

Fig. 4 Model for determining targets for mitigating VAT risks on transactions on B2B digital platforms. Source: Suggested by the authors of the article based on the results of the study.

In the authors' opinion, the proposed model for mitigating VAT tax risks on the digital marketplace is universal for all business management systems and ERP systems used. 


\section{ENTREPRENEURSHIP AND SUSTAINABILITY ISSUES}

ISSN 2345-0282 (online) http://jssidoi.org/jesi/

2019 Volume 7 Number 2 (December)

http://doi.org/10.9770/jesi.2019.7.2(28)

\section{Conclusion}

Based on the results of the study, it can be concluded that the electronic marketplace can be considered as a convenient and affordable service for all types of business. Emerging-market countries are characterized by the continuity of market mechanisms used in international practice to achieve a unity of approaches to solving intercountry economic relations. The introduction of VAT in the territory of post-Soviet countries and Southeast Asia is no exception. The choice in favor of VAT, and not another indirect tax, was made, since VAT allows creating a system, which is compatible with European countries. Regarding the digital marketplace, companies get the opportunity to sell goods to end customers on $\mathrm{B} 2 \mathrm{C}$ or $\mathrm{C} 2 \mathrm{C}$ models, as well as to conclude large-scale and small-scale wholesale transactions on B2B and B2B2C models. At the same time, historically, in the EU countries, the USA and emerging-market countries, different taxation systems have developed in relation to both direct and indirect taxes. The development of society digitalization, the provision of optimal tax treatment on the electronic marketplace can lead to a shift of business to transactions in a specific tax jurisdiction.

In international practice, the experience of introducing VAT for transactions on the B2B marketplace where transactions have not been previously subject to VAT is of interest, provided that the tax and regulatory system of the jurisdiction under study is assessed as a system with increased business risks. The above calculations showed that a B2B non-resident is in unequal conditions compared to a resident, and the difference in the calculated VAT rates is significant. But, at the same time, the obligation to pay VAT did not provoke the decision of foreign companies to move to the e-commerce marketplace in other jurisdictions, however, sales volumes decreased both on the part of residents and non-residents. In the authors' opinion, this testifies to the intentions of companies to expand their business capabilities and strengthen its competitiveness by participating in the digital marketplace of emerging-market economies, and the market itself is assessed as promising. However, the risk zones identified during the study predetermined that there is an urgent need to perform all necessary actions to optimize taxation and prevent tax risks on $\mathrm{B} 2 \mathrm{~B}$. This necessitates the development of a strategy for fiscal functions of all parties to a transaction to level out a conflict of interest. In this regard, a practical solution is the introduction of a model of determining targets for mitigating VAT risks on transactions on B2B digital platforms. In the authors' opinion, transnational companies, as well as companies carrying out transactions with a complex structure of interaction between businesses from different jurisdictions, start-up business at the B2B marketplace, these recommendations will allow tracking factors that must be taken into account for the impact of VAT on the transaction price. In the authors' opinion, the proposed model for mitigating VAT tax risks on the digital marketplace is universal for all business management systems and ERP systems used.

Undoubtedly, in addition to the developed internal tax strategy, it is also necessary to develop an external one relating to informing transaction participants and potential interested parties. First of all, this is associated with reputation risks, which may be the result of incorrectly interpreted data about a company in the media, the Internet. In turn, this increases the need for wider disclosure of information in corporate reporting and participation in the implementation of global initiatives to ensure taxation transparency. Based on the results of the study, it was determined that the disclosure of information on B2B transactions, indirect taxes and tax risks in corporate reporting is not imputed by regulators, is inconsistent, unstructured. In the authors' opinion, proactive information disclosure in corporate public B2B reporting is possible only if the company considers the information requests of users significant, and the cost of preparing such information does not exceed the expected effects. 


\section{ENTREPRENEURSHIP AND SUSTAINABILITY ISSUES}

ISSN 2345-0282 (online) http://jssidoi.org/jesi/

2019 Volume 7 Number 2 (December)

http://doi.org/10.9770/jesi.2019.7.2(28)

\section{References}

Adams S., Simnett R. 2011. Integrated Reporting: An Opportunity for Australia's Not-for-Profit Sector. Australian Accounting Review, 24 (2), 292-301. http://dx.doi.org/10.1111/j.1835-2561.2011.00143.x

Asongu, S.A. 2012. On the effect of foreign aid on corruption. Economics Bulletin, 32(3), 2174-2180.

Bach, S., Hubbert, M., Walter M. 2000. Taxation of E-Commerce: Persistent Problems and Recent Developments, Vierteljahrshefte zur Wirtschaftsforschung, 69(4), 657-678. http://dx.doi.org/10.3790/vjh.69.4.657

Bastiaens, I., Rudra, N. 2016. Trade liberalization and the challenges of revenue mobilization: Can international financial institutions make a difference? Review of International Political Economy, 23(2), 261-289. http://dx.doi.org/10.1080/09692290.2016.1149088

Besley, T., and Persson, T. 2013. Taxation and development. In Handbook of public economics, 5, 51-110. http://dx.doi.org/10.1016/B978-0-444-53759-1.00002-9

Borowiecki, K. J., Navarrete, T. 2018. Fiscal and economic aspects of book consumption in the European Union. Journal of Cultural Economics, 42(2), 309-339.

Bittman, B., Davies, A., Russell, W., \& Goussakova, E. 2017. Advance Placement and The Achievement Gap in the 21st Century: A Multiple Linear Regression of Marginalized Populations in AP Enrollment.Research In Social Sciences And Technology, 2(2). Retrieved from http://ressat.org/index.php/ressat/article/view/46

Brazys, S., Elkink, J.A., Kelly, G. 2017. Bad neighbors: how co-located Chinese and World Bank development projects impact local corruption in Tanzania. The Review of International Organizations, 12(2), 227-253.

Brülhart, M., Parchet, R. 2014. Alleged tax competition: The mysterious death of bequest taxes in Switzerland. Journal of Public Economics, 111, 13-78. https://doi.org/10.1016/j.jpubeco.2013.12.009

Dorofeyev M., Kosov M.E., Ponkratov V., Masterov A., Karaev A., Vasyunina M. 2018. Trends and prospects for the development of blockchain and cryptocurrencies in the digital economy. European Research Studies Journal. 21(3), 429-445.

Dunets, A., Latysheva, O., Bitter, N., Vakhrushev, I., Shichiyakh, R., \& Zhuruli, G. 2019. The economic and infrastructural basis for the development of tourist space: The essence, structure and typology. Journal of Environmental Management and Tourism, 10(2), 319-327. http://doi:10.14505/jemt.v10.2(34).05

Cui Y, Liu X. 2010. Provincial tax competition and environmental pollution: based on panel data from 1998 to 2006 in China. Finance Econ 36(4), 46-55

Dhillon, A., Wooders, M., \& Zissimos, B. 2007. Tax competition reconsidered. Journal of Public Economic Theory, 9(3), $391-423$.

Dincecco, M., Katz, G. 2016. State capacity and long-run economic performance. The Economic Journal, 126(590), 189-218. https://doi.org/10.1111/ecoj.12161

Gennaioli, N., Voth, H. 2015. State capacity and military conflict. The Review of Economic Studies, 82(4), 1409-1448. http://doi.org/10.1093/restud/rdv019

Goloshchapova, L. V., Plaskova, N. S., Prodanova, N. A., Yusupova, S. Y., \& Pozdeeva, S. N. 2018. Analytical review of risks of loss of profits in cargo transportation. International Journal of Mechanical Engineering and Technology, 9(11), 1897-1902.

Goryushkina, N. E., Vakhrushev, I. B., Akhmetova, M. K., Otto, O. V., Pesotskaya, E. V., \& Voinova, N. E. 2018. The world hotel market: Current state and development trends. International Journal of Mechanical Engineering and Technology, 9(12), 618-627.

Gugl, E., Zodrow, G. R. 2015. Competition in business taxes and public services: Are production-based taxes superior to capital taxes? National Tax Journal, 68(3S), 767-802. 


\section{ENTREPRENEURSHIP AND SUSTAINABILITY ISSUES}

ISSN 2345-0282 (online) http://jssidoi.org/jesi/

2019 Volume 7 Number 2 (December)

http://doi.org/10.9770/jesi.2019.7.2(28)

He, J., and Wang, H. C. 2009. Innovative knowledge assets and economic performance: The asymmetric roles of incentives and monitoring. The Academy of Management Journal, 52, 919-938. https://doi.org/10.5465/amj.2009.44633414

Hyman, R. 2015. Austeritariansim in Europe: What options for Resistance? In Social Policy in the European Union. 24, 97-126.

Information on Rosnano Financial Statements, Date of Access 31.07.2019 г. https://www.rusnano.com/about/highlights/financial-report

Information on Danfoss Financial Statements, Date of Access 31.07.2019 г. https://finotchet.ru/articles/1199/

Kaplan, A. M., Haenlein, M. 2009. The fairyland of second life: virtual social worlds and how to use them. Buisness Horizon, 52(6), pp. $563-572$.

Karpova T.P., Petrov A.M., Antonova O.V. 2018. Directions of Accounting Development in the Conditions of Digitalization. Journal of Research in Dynamical \& Control Systems, 10(07), 11 7-125

Keen, M., Lockwood, B. 2010. The value added tax: Its causes and consequences. Journal of Development Economics, 92(2), 138-151.

Keeny, R. L. 1999. The value of internet commerce to the customer. Management Science, 45(4), 533-542. https://doi.org/10.1287/mnsc.45.4.533

Kevorkova, Z.A., Petrov, A.M., Savina N.V. 2019. Towards liabilities of corporate systems. International Journal of Civil Engineering and Technology, 10(2), 1582-1593

Kolesnichenko, E., Ozerov, I., Safonova, N., Malitskaya, V. 2018. Digitalization of management as the way of increasing the social and labor activity of young people. Proceedings of 32nd International Business Information Management Association Conference (IBIMA) Vision 2020: Sustainable economic development and application of innovation management from regional expansion to global growth, pp. $2955-2963$

Kosorukov, O. A., \& Maksimov, D. A. 2016. Methods of assessing efficiency of wildfire monitoring systems functioning. Research Journal of Pharmaceutical, Biological and Chemical Sciences, 7(6), 517-529.

Korableva, O. N., Kalimullina, O. V., Zaytseva, A. A., \& Larionov, A. I. 2018. Elaboration of database for the subject domain of innovation and economic growth potential. Paper presented at the Proceedings of the 31st International Business Information Management Association Conference, IBIMA 2018: Innovation Management and Education Excellence through Vision 2020, 6065-6073.

Korableva, O.N., Kalimullina, O.V., Mityakova, V.N. 2019. Designing a System for Integration of Macroeconomic and Statistical Data Based on Ontology. Advances in Intelligent Systems and Computing, 998, p. 157-165

Lebedeva, T. E., Dzagoyeva, M. R., Kobersy, I. S., \& Ikoev, S. K. 2016. Corporate governance issues and control in conditions of unstable capital risk. International Journal of Economics and Financial Issues, 6(1S), 25-32.

Leonteva, L. S., Maximov, D. A., Kurbanov, S. A., Afanasyev, I. V., Melnikova, T. E., \& Rezakov, R. G. 2018. Information services and development of effective urban management. International Journal of Civil Engineering and Technology, 9(11), $2518-2525$.

Lindvall, J. 2011. The Political Foundations of Trust and Distrust: Reforms and Protests in France. West European Politics 34(2), 296-316.

Lymar, M.P., Kevorkova, Z.A., Petrov, A.M. 2018. The convergence of national and international accounting standards: Chinese experience. International Journal of Civil Engineering and Technology, 9(13), 82-94

Mail Group Financial Statements, Date of Access 31.07.2019 г. https://corp.mail.ru/ru/investors/reports/

Maguth, B. M., \& Koskey, K. L. K. 2019. Preparing urban youth to live-up to their civic promise? Evaluating youth positionality of civic engagement using an arts-based instrument. Journal of Social Studies Education Research, 10(1), 1-37.

Morkovina, S.S., Malitskaya, V.B., Panyavina, E.A., Sibiryatkina, I.V. (2018) Export potential and measures to support small and mediumsized enterprises. European Research Studies Journal, 2018, Volume XXI, Special Issue 1, 303-314 


\section{ENTREPRENEURSHIP AND SUSTAINABILITY ISSUES}

ISSN 2345-0282 (online) http://jssidoi.org/jesi/

2019 Volume 7 Number 2 (December)

http://doi.org/10.9770/jesi.2019.7.2(28)

Papagiannidis, S., Bourlackis, M., Li, F. 2008. Making real money in virtual worlds: MMORPGs and emerging business opportunities, challenges and ethical implications in metaverses. Technological Forecasting \& Social Change, 75, 610-622. http://doi.org/10.1016/j.techfore.2007.04.007

Peacock A., Agnew M. (2012) More to Eu place of supply rules changes than meets the eye. Interbational Tax Review, 23(5), 38-48.

Peshkova, G., Antohina, Y., \& Smirnova, N. 2017. Measures to improve Russian federal strategy of the construction materials industry development. Journal of Business and Retail Management Research, 11(3), 39-46.

Ponomareva, N.V., Zvereva, A.O., Golubtsova, E.V., Ilyashenko, S.B. 2019. Tax incentives for use of alternative energy sources in the Russian Federation. International Journal of Energy Economics and Policy, 9(4), 144-148.

Plaskova, N. S., Prodanova, N. A., Zatsarinnaya, E. I., Korshunova, L. N., \& Chumakova, N. V. 2017. Methodological support of organizations implementing innovative activities investment attractiveness estimation. Journal of Advanced Research in Law and Economics, 8(8), 2533-2539. http://doi:10.14505/jarle.v8.8(30).25

Prosser, T. 2016. Economic Union without Social Union. The Strange Case of the European Social Dialogue. Journal of European Social Policy 26(5), 460-472. https://doi.org/10.1177/0958928716664298

Rene, N. G. 2009. Taxation of internet gaming and gambling in the European Union. ERA Forum 10(4), 525-531. https://doi.org/ $10.1007 / \mathrm{s} 12027-009-0144-1$

Rinaldi, L., Unerman, J. \& De Villiers, C. 2018. Evaluating the Integrated Reporting journey: insights, gaps and agendas for future research, Accounting, Auditing \& Accountability Journal, 31(5), 243-256. https://doi.org/10.1108/AAAJ-04-2018-3446

Rixen, T. 2011. Tax competition and inequality: The case for global tax governance. Global Governance: A Review of Multilateralism and International Organizations, 17(4), 447-467. https://doi.org/10.2139/ssrn.1488066

Romasheva, N. V., Kruk, M. N., \& Cherepovitsyn, A. E. (2018). Propagation perspectives of CO2 sequestration in the world. International Journal of Mechanical Engineering and Technology, 9(11), 1877-1885.

Rupeika-Apoga, R., Zaidi, H.S., Thalassinos, E.Y. \& Thalassinos, I.E. 2018. Bank Stability: The Case of Nordic and Non-Nordic Banks in Latvia. International Journal of Economics \& Business Administration, 6(2), 39-55.

Sasongko, G., Huruta, A.D., Wardani, A. 2019. Does the Wagner's Law exist in a strategic national area? An evidence from Kedungsepur - Indonesia. Insights into Regional Development, 1(2), 99-117. https://doi.org/10.9770/ird.2019.1.2(2)

Sazanov, O. V., \& Akhmetshin, E. M. 2016. Tax monitoring as an alternative to existing forms of tax control in Russia. Journal of Economics and Economic Education Research, 17(Special Issue), 15-20.

Schlosser, A. E. 2006. Learning through virtual product experience: The role of imagery on true versus false memories. Journal of Consumer Research, 33(3), 377-383.

Shatunova, O., Anisimova, T., Sabirova F., Kalimullina, O. 2019. STEAM as an Innovative Educational Technology. Journal of Social Studies Education Research, 10(2), 131-144.

Sharafutdinov, R., Gerasimov, V., Akhmetshin, E., Karasik, E., \& Kalimullina, O. 2018. Inclusive development index in Russia: analysis, methods, possibility of application. National Academy of Managerial Staff of Culture and Arts Herald, 2(2), 1-4.

Seelkopf, L., Lierse, H., Schmitt, C. 2016. Trade liberalization and the global expansion of modern taxes. Review of International Political Economy, 23(2), 208-231. https://doi.org/10.1080/09692290.2015.1125937

Silva, A. 2014. VAT Registration in Europe: A Review. Publishing Research Quarterly, 30(1), 152-165. https://doi.org/10.1007/s12109014-9350-y

Singareddy, R. R. R., Ranjan, P., Balamurugan, A., \& Shabana, C. (2019). Financial inclusion remodeling: Including the excluded masses. Space and Culture, India, 6(5), 178-188. http://doi:10.20896/SACI.V6I5.375 


\section{ENTREPRENEURSHIP AND SUSTAINABILITY ISSUES}

ISSN 2345-0282 (online) http://jssidoi.org/jesi/

2019 Volume 7 Number 2 (December)

http://doi.org/10.9770/jesi.2019.7.2(28)

Tarman, B. 2018. Editorial: 2018 (3)2. Research in Social Sciences and Technology, 3(2), i-ii. Retrieved from http://ressat.org/index.php/ressat/article/view/370

Thalassinos, I.E., Hanias, P.M. and Curtis, G.P. 2012. Time series prediction with neural networks for the Athens Stock Exchange indicator. European Research Studies Journal, 15(2), 23-31.

Trofimova, L., Prodanova, N., Korshunova, L., Savina, N., Ulianova, N., Karpova, T., \& Shilova, L. 2019. Public sector entities' reporting and accounting information system. Journal of Advanced Research in Dynamical and Control Systems, 11(8 Special Issue), 416-424.

Voronkova, O. Y., Iakimova, L. A., Frolova, I. I., Shafranskaya, C. I., Kamolov, S. G., \& Prodanova, N. A. 2019. Sustainable development of territories based on the integrated use of industry, resource and environmental potential. International Journal of Economics and Business Administration, 7(2), 151-163.

Wahl, I., Kastlunger, B., Kirchler, E. 2010. Trust in Authorities and Power to enforce tax compliance: An empirical analysis of the slippery slope framework. Law and Policy, 32(4), 383-406. https://doi.org/10.1111/j.1467-9930.2010.00327.x

Wei, H. 2018. The analysis on Chinese e-commerce tax losses based on the perspective of information asymmetry. Electronic Commerce Research, 61, 1-27.

Yapara, B.K., Bayrakdara, S., Yaparb, M. 2015. The Role of Taxation Problems on the Development of E-Commerce. Procedia - Social and Behavioral Sciences. 195(3), 642-648.

Ravil AKHMADEEV, British Doctor of Philosophy degree $(\mathrm{PhD})$ standard, Associate Professor, Department of Accounting and Taxation, Plekhanov Russian University of Economics, Russian Federation. Research interest: Taxes and taxation, Transfer pricing in taxation, International taxation, Finance and credit, Tax regulation of the economy.

ORCID ID: https://orcid.org/0000-0002-7526-0144

Tatiana MOROZOVA, Associate Professor, Department of Accounting and Taxation, Plekhanov Russian University of Economics, Russian Federation. Research interest: International Financial Reporting Standards, Taxes and taxation, Small Business Accounting.

ORCID ID: https://orcid.org/0000-0003-3833-2783

Olga VORONKOVA, doctor of Economics, Professor of management, business organization and innovation Department, Altai state University. Has the status of an expert of the Eurasian technological platform "Technologies of food and processing industry of agriculture - healthy food". Research interests - sustainable development of territories, innovation, technological and social entrepreneurship.

ORCID ID: https://orcid.org/0000-0002-3106-4643 
Alexey SITNOV, Doctor of Economics, Professor of the Accounting, Analysis and Audit Department of the Russian Federation. Financial University of the Russian Federation Government of the Russian Federation. Research interests accounting expertise, state financial control, audit, departmental interaction, efficiency of activity

ORCID ID: https://orcid.org/0000-0003-2221-4037

Register for an ORCID ID:

https://orcid.org/register

Copyright (C) 2019 by author(s) and VsI Entrepreneurship and Sustainability Center

This work is licensed under the Creative Commons Attribution International License (CC BY).

http://creativecommons.org/licenses/by/4.0/

cc) (i) Open Access 